\title{
Organization strategies in the Rey-Osterrieth Complex Figure in children with ADHD
}

\author{
Josefina Rubiales, Daiana Russo, Rocío González and Liliana Bakker \\ Universidad Nacional de Mar del Plata (Argentina)
}

\begin{abstract}
The aim of this study was to analyze ADHD diagnosed children's process of copy, organization strategies and recall phase of Rey-Osterrieth Complex Figure. This study corresponds to an ex post facto retrospective design with two groups, one quasi control. Seventy children between 8 and 14 years old were evaluated; 35 with ADHD and 35 without these diagnoses, paired by sex, age and instruction level. To reach the proposed objective, the process of copying, organizational strategies and memory of the ReyOsterrieth Complex Figure were evaluated. The Rey-Osterrieth Complex Figure is a test which consists of copying phase and posterior playing back memory phase of a complex geometric pattern. Results showed a lower yield for the group with ADHD both in copy and memory process, with greater use of $\mathrm{C}$ and $\mathrm{D}$ types of copy reproduction, being the use of type D expected for younger children. These results allow further analysis of the performance of children with ADHD regarding organizational strategies providing expertise in the conceptualization, evaluation and treatment of the disorder.
\end{abstract}

Keywords: Children, ADHD, organization, Rey-Osterrieth Complex Figure.

Estrategias de organización en la Figura Compleja de Rey en niños con TDAH. El objetivo del presente estudio fue analizar el proceso de copia, las estrategias de organización y la fase de memoria en el desarrollo de la Figura Compleja de Rey en niños con diagnóstico de TDAH. El estudio se corresponde con un diseño de tipo ex post facto retrospectivo con dos grupos, uno cuasi control. Se evaluaron 70 niños de 8 a 14 años, 35 niños con diagnóstico de TDAH, y 35 niños sin el diagnóstico, emparejados por sexo, edad y nivel de instrucción. Para cumplir con los objetivos propuestos se evaluó el proceso de copia, las estrategias de organización y la memoria en la prueba Figura Compleja de Rey, la cual consiste en la copia y posterior reproducción de memoria de un dibujo geométrico complejo. Los resultados evidenciaron un menor rendimiento para el grupo con TDAH tanto en copia como en memoria, con mayor utilización de los tipos C y D de reproducción de copia, siendo este último tipo de copia esperable para niños de menor edad. Estos resultados permiten profundizar el análisis del desempeño de los niños con TDAH en relación a las estrategias de organización aportando conocimientos en la conceptualización, la evaluación y el tratamiento del trastorno.

Palabras clave: Niños, TDAH, organización, Figura Compleja De Rey.

Correspondence: Josefina Rubiales. IPSIBAT-CONICET. Facultad de Psicología. Universidad Nacional de Mar del Plata (Argentina). Email: josefinarubiales@ gmail.com 
Attention Deficit Hyperactivity Disorder (ADHD) is the most frequent neurodevelopmental disorder initiated in infancy (Rodillo, 2015). ADHD is currently defined as a persistent pattern of symptoms of inattention and/or hyperactivity-impulsivity that is more frequent and severe than typically observed in individuals with a similar degree of development (American Psychiatric Association, 2013). It is a complex and heterogeneous syndrome, with wide and varied symptomatic characteristics, whose symptoms have a major impact on the development of the individual and interfere with their social, emotional and cognitive functioning, affecting not only the child but also the peer group and their family (Cardo \& Servera, 2008, Cardo et al., 2011; Fernández-Jaén et al., 2016). It is understood as a complex diagnosis, of early onset and chronic evolution (Cardoso-Moreno, Tomás-Aragonés, \& Rodríguez-Ledo, 2015; García, Fernández, Loew, \& Pérez, 2016; Missawa, Dadalto, \& Rossetti, 2014).

ADHD global prevalence studies are estimated to be between 5.9 and $7.1 \%$ (Willcutt, 2012). Regarding etiology, it is argued that there is no single factor that may be enough to determine and although still not identified a single cause. The findings are consistent with a multi-causal hypothesis (Catelan-Mainardes, 2010), due to a complex combination of genetics, biological and environmental factors (Etchepareborda, Díaz-Lucero, \& De-Ramón, 2011).

Several ADHD researches agree that its symptoms are due to a cognitive deficit (Barkley, 2011; Mayor \& Garcia, 2011; Robinson \& Tripp, 2013), in which executive functions are compromised (FE) (Álvarez, 2006; Corbett, Constantine, Hendren, Rocke, \& Ozonoff, 2009). Planning is one of the executive functions, a superior cerebral function that refers to setting an objective, making a mental test, applying the chosen strategy and value the achievement or failure of the proposed objective (Tirapu-Ustárroz, Muñoz-Céspedes, Pelegrín-Valero, \& Albéniz-Ferreras, 2005). It involves the capacity to identify and organize the necessary steps and elements to carry out an intention or achieve an objective, for which changes should be conceived from present circumstances, analyze alternatives, ponder and make choices (Soprano, 2003).

Diverse research has evidenced a deficit in planning in children with ADHD (Barkley, 2003; Nigg, Hinshaw, Carte, \& Treuting, 1998;Willcutt, Doyle, Nigg, Faraone, \& Pennington, 2005), showing that they lack of organizational strategies and the information storage is performed in temporal form in short term memory, presenting greater difficulties for its storage in long term memory (Montoya, Varela, \& Dussan, 2011). While these children are not characterized for showing deficit in their mnemonic abilities (Barkley, 2006), it is expected that they show memory alterations associated to the necessary abilities for the adequate organization, storage, selection and evocation of the information, due to the execution in some components of the memory depends on the 
adequate executive function (Narbona \& Crespo, 2005). The low performance in memory tasks would be based in the inadequate executive function that children with ADHD present (Caballo \& Simon, 2000).

One of the classic neuropsychological instruments that not only evaluates memory and visual-constructional capacity, but also implies abilities of planning and organization, is the Rey-Osterrieth Complex Figure (Da Silva, Pecanha, Charchat-Fichman, Oliveira, \& Correa, 2016; Strauss, Shermann, \& Spreen, 2006). It was designed by Rey in 1941, and later Osterrieth (1944) elaborated a system of scoring to standardize the original procedure. Due to the complexity that the figure presents, it is considered that it also evaluates, in the copy phase, the cognitive processes linked to strategies of organization, so it can be considered as a useful instrument for the evaluation of executive function (Watanabe et al., 2005).

Martín-González et al. (2008), Robinson and Tripp (2013) and Rizzutti et al. (2008) have shown that children without ADHD draw the initial design with a higher fidelity than children with ADHD, and in regards to visual memory performance, the studies of Bara-Jiménez et al. (2003) and Robinson and Tripp (2013) have evidenced lower performance in children with ADHD. However, other studies did not find significant differences in the immediate recall phase (Filippetti \& Mias, 2009; Martín-González et al., 2008).

Thereby it is noted that the studies which analyze the performance of children with ADHD in the recall phase do not result conclusive, and while there has been research that analyzed strategies of copy (Da Silva, 2006; Watanabe et al., 2005), these have not been performed in children with ADHD, therefore the aim of the study was to analyze the process of copy, strategies of organization and the memory phase in the development of the Rey-Osterrieth Complex Figure in children diagnosed with ADHD.

\section{METHOD}

\section{Type of study}

It corresponds to an ex post facto retrospective design with two groups, one of quasi control, according to Montero and Leon (2007) classification.

\section{Participants}

The sample consisted of 70 children of the city of Mar del Plata, Argentina, divided in two groups, selected by a non-probabilistic sample. The clinical sample consisted of 35 children diagnosed with ADHD derived by neurological doctors of the city health centers, 25 males and 10 females, with ages between 8 and 14, with an average of 9.94 years and a standard deviation of 1.87. Control sample consisted of 35 children without diagnose of ADHD paired by sex, age and level of instruction; with an 
average age of 10.14 and a standard deviation of 1.75 . Inclusion criteria for the clinical sample was: submit diagnosis of ADHD according to derived doctors, meet the diagnosis criteria for ADHD according to DSM-5 (APA, 2013), present values above the cutoff expected in the specific scale of ADHD, and an intelligence quotient (I.Q) superior to 70. The criteria of inclusion for the control sample was: not meet the diagnosis criteria for ADHD, present values below the cutoff expected in the specific scale of ADHD, and an intelligence quotient (I.Q) superior to 70. Children with neurological or psychiatric diseases and learning disorders were excluded.

\section{Instruments}

To confirm medical diagnosis of ADHD according to DSM-5 criteria (APA, 2013), it was administered the standardized scale of Swanson, Nolan and Pelham -SNAP IV-, in Spanish version validated in Argentina (Granana et al., 2006), both parents and teachers version. To discard intellectual deficit, it was administered the Kaufman`s Brief Intelligence Test -K-BIT (Kaufman, 2000).

In order to evaluate the process of copy, organizational strategies and memory, the Rey-Osterrieth Complex Figure (Rey, 1997) was used, which consists of copying and later recalling and reproduction of the complex geometrical pattern. The child `s task is to copy the drawing, with the model in sight, and then draw it again after a three minutes interval without the model in sight. In both moments, the child must use a different color every 45 seconds, thereby can be distinguished 6 times, one per color.

For the present study, two types of scoring elaborated by Osterrieth (1944) were used. On the one hand, the figure was analyzed according to the total scoring of copy and immediate recall, so for that it is divided into 18 parts (Figure 1), which were scored according to placement and accuracy: correct element and correctly situated $=1$ point; deformed or incomplete and wrongly situated $=0.5$; and absent $=0$ points.

Figure 1. Outline of the division of the Rey-Osterrieth Complex Figure according to Osterrieth (1994)

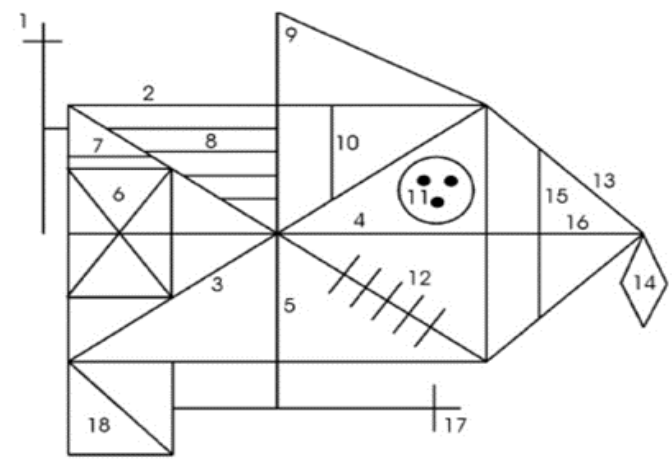


On the other hand, the figure was analyzed according to the type of reproduction as stated in the description manual (Rey, 1997): (I) Construction of the frame; (II) Details within the frame; (III) General outline; (IV) Detail juxtaposition; (V) Details on confused background; (VI) Reduction to a familiar outline; and (VII) Scribble.

For the present study, the types of reproduction were coded as Type A (pairing Type I and II), Type B (corresponding to Type III), Type C (corresponding to type IV), Type D (corresponding to Type V) and Type E (corresponding to Type VI).

Lastly, to analyze organizational strategies in the copy, it was administered the procedure by Stern et al. (1999) denominated The Boston Qualitative Scoring System (BQSS), that establishes the division of the figure in three hierarchical groups (Configural Elements, Clusters and Details). For this study, was analyzed the quantity of elements drawn of the three hierarchical groups in the six times previously described (Figure 2).

Figure 2. The Boston Qualitative Scoring System (BQSS) of the Rey-Osterrieth Complex Figure with the division of three hierarchical groups

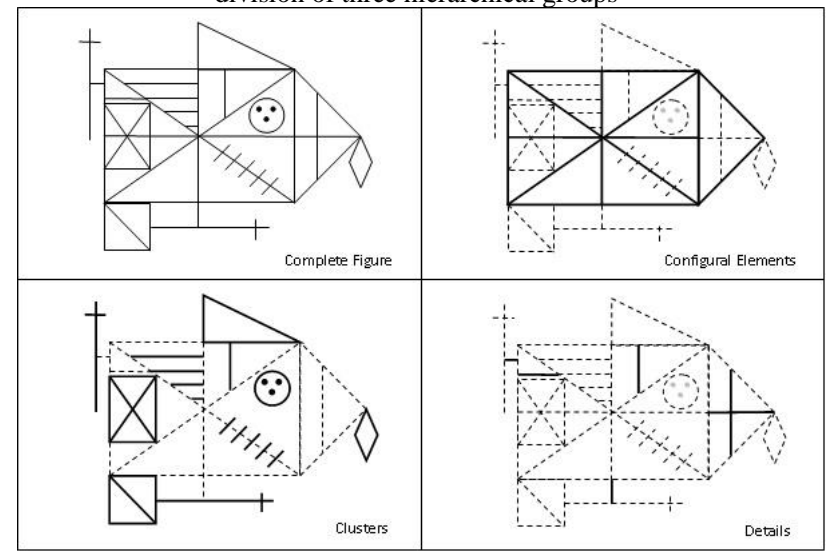

\section{Procedure}

Current study is part of a major research project belonging to the Research Group "Human Behavior, Genetics and Environment", approved by the Science and Technology department of the National University of Mar del Plata (UNMdP), Argentina. Contact with children with ADHD and their parents was established through two Health Institutions. They were summoned to the installations of the Institute of Basic, Applied Psychology and Technology (IPSIBAT) of the Psychology Faculty of the UNMdP to proceed with the individual evaluation. On the other hand, the contact and evaluation was preceded with the children of the control sample, and questioners for their parents and teachers were administered. The participation was volunteered and 
subject to the children assent and the informed consent of the parents. During the development of the task, ethical principles of research with human being were respected, undertaking the necessary conditions to protect confidentiality and act in benefit of the participants.

\section{Data analysis}

Package SPSS version 19 was used to execute statistical analysis. Descriptive statistical analysis (media, standard deviation and frequency) was done as well as correlation analysis. Differences between two groups were analyzed using the MannWhitney U-test for two independent samples. This test was used due to the size of the sample, as it is an alternative to Student's t-test about difference of averages when the assumptions in which $\mathrm{t}$ test is based (normality and homoscedasticity) are not met (Pardo \& Ruiz, 2000). Additionally, it was calculated, for each one of the variables, the effect size Cohen's d, which indicates that the size of the effect could be great (greater to .8 ), medium (close to .5) or less (less than .2) (Quezada, 2007).

\section{RESULTS}

In order to demonstrate the performance Rey Complex Figure test for clinical and control group in the first instance descriptive statistical analysis, Mann-Whitney U-test and the effect size $d$ of Cohen's were made for intragroup copy phase and memory results. This results show significant difference with a great effect size between copy and memory both for clinical $(d=1.21)$ and control group $(d=2.27)$, being greater difference in control group.

In order to compare total results of copy and memory between control and clinical group, the corresponding analysis were administered presented in table 1.

Table 1. Descriptive statistics, results of the U-Mann-Whitney test and Cohen's size of effect $d$ for the results in copy and recall discriminated in function of the group pertinence

\begin{tabular}{|c|c|c|c|c|c|c|}
\hline \multirow{3}{*}{$\frac{\text { Rey Figure }}{\text { Totals }}$} & \multicolumn{4}{|c|}{ Descriptive } & \multirow{3}{*}{$\begin{array}{l}\text { U-Mann-Whitney Test } \\
\text { Sig. asintót. (bilateral) }\end{array}$} & \multirow{3}{*}{$\begin{array}{c}\text { Cohen's Effect } \\
d\end{array}$} \\
\hline & \multicolumn{2}{|c|}{ Control Group } & \multicolumn{2}{|c|}{ Clinical Group } & & \\
\hline & $M$ & $D E$ & $M$ & $D E$ & & \\
\hline Copy & 23.00 & 5.28 & 18.14 & 9.06 & $.01 * *$ & .65 \\
\hline Recall & 10.85 & 5.38 & 7.65 & 5.52 & $.01 * *$ & .58 \\
\hline
\end{tabular}

**Significant difference to level .01(bilateral).

The results show significant difference between clinical and control group, both in copy $(d=.65)$ and memory $(d=.58)$ with a medium effect size, the control group presenting better performance.

Table 2 shows the comparison of reproduction type in copy between clinical and control group. 
RUBIALES et al. Organization strategies in the Rey-Osterrieth Complex Figure...

Table 2. Descriptive statistics, results of the U-Mann-Whitney test and Cohen's size of effect d for the type of reproduction in copy in function of the clinical and control group

\begin{tabular}{|c|c|c|c|c|c|c|}
\hline \multirow{2}{*}{ Rey Figure } & \multicolumn{4}{|c|}{ Descriptive } & \multirow{3}{*}{$\begin{array}{l}\text { U-Mann-Whitney Test } \\
\text { Sig. asintót. (bilateral) }\end{array}$} & \multirow{3}{*}{$\frac{\text { Cohen's Effect }}{d}$} \\
\hline & \multicolumn{2}{|c|}{ Control Group } & \multicolumn{2}{|c|}{ Clinical Group } & & \\
\hline Copy & $M$ & $D E$ & $M$ & $D E$ & & \\
\hline Type A & .09 & .28 & .09 & .28 & 1.00 & 0 \\
\hline Type B & .14 & .35 & .09 & .28 & .45 & .15 \\
\hline Type C & .71 & .45 & .43 & .50 & $.01 * *$ & .58 \\
\hline Type D & .06 & .23 & .40 & .49 & $.00^{* *}$ & .88 \\
\hline Type E & .00 & .00 & .00 & .00 & 1.00 & 0 \\
\hline
\end{tabular}

The results show significant difference between clinical and control group for the reproduction type $\mathrm{C}$ with a medium effect size $(d=.58)$, being observed greater quantity in control group. Likewise, between-group significant differences were observed for the reproduction type D with a great effect size $(d=.88)$, but in this case it was noted a greater quantity in clinical group; which can be observed as well in the graph 1 .

Graph 1. Type of copy reproduction for control and clinical group

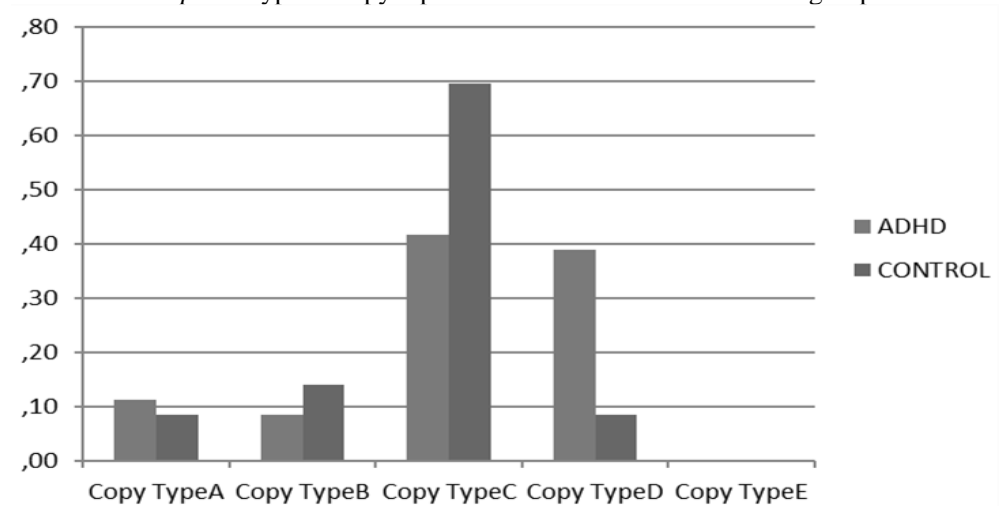

Furthermore, it has been observed that children with ADHD aged 8 to 10 years old $(n=21)$ made more copies type $\mathrm{D}(n=11)$ and type $\mathrm{C}(n=9)$ than children with ADHD aged 11 to 14 year olds $(n=14)$, who made more copies type $\mathrm{C}(n=6)$, A $(n=3)$ and $\mathrm{D}(n=3)$.

Percentage of performed elements according to six times of the copy in control and clinical group are presented in table 3 .

The results show significant statistical differences between clinical and control group for time 3 with a medium effect size $(d=.56)$, observing greater percentage of elements performed in control group.

Table 4 shows the percentage of elements performed in the three hierarchical groups of the copy of the figure in control and clinical group. 
RUBIALES et al. Organization strategies in the Rey-Osterrieth Complex Figure...

Table 3. Descriptive statistics, results of the U-Mann-Whitney test and Cohen's size of effect d for the percentage of elements performed according to copy times

\begin{tabular}{|c|c|c|c|c|c|c|}
\hline \multirow{3}{*}{$\begin{array}{l}\text { Rey Figure } \\
\text { Copy }\end{array}$} & \multicolumn{4}{|c|}{ Descriptive } & \multirow{3}{*}{$\begin{array}{l}\text { U-Mann-Whitney Test } \\
\text { Sig. asintót. (bilateral) }\end{array}$} & \multirow{3}{*}{$\begin{array}{c}\text { Cohen's Effect } \\
d\end{array}$} \\
\hline & \multicolumn{2}{|c|}{ Control Group } & \multicolumn{2}{|c|}{ Clinical Group } & & \\
\hline & $M$ & $D E$ & $M$ & $D E$ & & \\
\hline Time 1 & 15.37 & 7.49 & 16.87 & 7.77 & .36 & .19 \\
\hline Time 2 & 15.24 & 10.88 & 16.46 & 9.04 & .52 & .12 \\
\hline Time 3 & 19.46 & 10.09 & 14.29 & 8.00 & $.02 *$ & .56 \\
\hline Time 4 & 16.46 & 9.54 & 12.52 & 9.31 & .13 & .41 \\
\hline Time 5 & 9.39 & 11.28 & 7.07 & 8.89 & .56 & .22 \\
\hline Time 6 & 2.99 & 10.52 & 1.63 & 5.02 & .94 & .16 \\
\hline
\end{tabular}

*Significant difference to level .05 (bilateral).

Table 4. Descriptive statistics and results of difference of averages for the percentage of elements performed in the three hierarchical groups of the copy of the figure

\begin{tabular}{|c|c|c|c|c|c|c|}
\hline \multirow{3}{*}{$\begin{array}{l}\text { Rey Figure } \\
\text { Copy }\end{array}$} & \multicolumn{4}{|c|}{ Descriptive } & \multirow{3}{*}{$\begin{array}{l}\text { U-Mann-Whitney Test } \\
\text { Sig. asintót. (bilateral) }\end{array}$} & \multirow{3}{*}{$\begin{array}{c}\text { Cohen's Effect } \\
d\end{array}$} \\
\hline & \multicolumn{2}{|c|}{ Control Group } & \multicolumn{2}{|c|}{ Clinical Group } & & \\
\hline & $M$ & $D E$ & $M$ & $D E$ & & \\
\hline Configural Elements & 8.57 & 3.42 & 2.38 & 31.08 & $.00 * *$ & .95 \\
\hline Cluster & 7.62 & 4.20 & 7.62 & 14.70 & .93 & 0 \\
\hline Details & 6.19 & 3.39 & 7.14 & 28.94 & .31 & .34 \\
\hline
\end{tabular}

**Significant difference to level .01 (bilateral)

The results show a significant difference between clinical and control group for the percentage of the elements in Configural Elements with a great effect size $(d=.95)$, observing a greater percentage of elements performed in control group.

Lastly, Mann-Whitney U test and effect size Cohen's d were performed in order to analyze the percentage of elements performed according to the six times and the three hierarchical groups in control and clinical group. The results show that clinical group presents higher scores in the two first times and lower scores in the remaining times. Also it has been observed significant differences between both groups for the percentage of elements in time 3 (configural elements and details) and time 4 (configural elements), with a medium effect size, observing greater percentage of elements of the Configural Elements performed in control group.

\section{DISCUSSION}

The aim of this study was to analyze the process of copy, strategies of organization and memory phase in the Rey-Osterrieth Complex Figure in children diagnosed with ADHD. In first place, results show that ADHD children present a lower performance both in copy and memory phase, and perform less quantity of elements of Configural Elements. Whereas that the performance in both groups in relation to the percentage of elements drawn in the two first times was similar, in the third time the percentage of elements performed by children with ADHD is lower, who complete the greater quantity of elements of the figure in the two first times, and then their performance decreases, performing lower quantity of Configural Elements. Children 
without ADHD made the copy in the four first times and complete the greater quantity of elements of the Configural Elements in the two following times.

With respect to the organizational strategies evaluated through the type of copy reproduction, the most used by children with ADHD are copy type C and D. The first one corresponds to juxtaposition of details, expected in children of 5 and 11 years old (Osterrieth, 1944), coinciding with a recent study (Moraes da Silva, 2016). Type D corresponds to the copy of details on confused background, mainly utilized in children of 5, 6 and 7 years old with low frequency, and vanishing in children of 8 years (Osterrieth, 1944), from which it can be inferred that children with ADHD use a type of copy expected for younger children. These results are consistent with previous studies that showed that children without ADHD draw the initial design with greater fidelity in the copy phase than children diagnosed (Martin-Gonzalez et al., 2008; Henao, 2003; Robinson \& Tripp, 2013). In order to success in the memory process, it is important that the information be coded to be stored, for which required attention, concentration and emotional state (Etchepareborda \& Abad-Mas, 2005).

Thereby, this study show that children with ADHD made the copy in less time, reproduced the parts of the figure with difficulties in order to achieve the configural elements, and mainly utilized the type of copy on confused background, which may show that the process of encoding information may be affected by the executive deficit typical of this diagnosis (Barkley, 2006), which also influences learning and memory process.

A line of work that detaches from the present study is to analyze the relationship between the executive performance and the Rey-Osterrieth Complex Figure in children with ADHD, using evaluation instruments that provide greater ecological validity so that it can be infer the functional capacity of the child in their daily activities.

It is important to mention one of the limitations of this study, which is related to the size of the sample, due to the drawbacks that are usually to evaluate patients diagnosed with some pathology and meeting all inclusion criteria required in a research design.

\section{REFERENCES}

Álvarez, J.B. (2006). Diagnóstico del trastorno de déficit de atención con/sin hiperactividad. Una visión desde la evidencia científica. Revista Pediatría de Atención Primaria, 8(4), 25-37.

American Psychiatric Association (2013). Diagnostic and Statistical Manual of Mental Disorders (5 Ed.). Washinton DC: Arlington, VA, American Psychiatric Publishing.

Bará-Jiménez, S., Vicuña, P., Pineda, D.A., y Henao, G.C. (2003). Perfiles neuropsicológicos y conductuales de niños con trastorno por déficit de atención/hiperactividad de Cali, Colombia. Revista de Neurología, 37(7), 608-615.

Barkley, R.A. (2003). Issues in the diagnosis of attention-deficit/hyperactivity disorder in children. Brain and Development, 25(2), 77-83. doi: 10.1016/S0387-7604(02)00152-3 
Barkley, R.A. (2006). Attention Deficit Hyperactivity Disorder: A Handbook for Diagnosis and Treatment (3rd edition). New York: Guilford Press.

Barkley, R.A. (2011). Is executive functioning deficient in ADHD? It depends on your definitions and your measures. The ADHD Report, 19(4), 1-10. doi: 10.1521/adhd.2011.19.4.1

Caballo, V.E., y Simón, M.A. (2002). Manual de Psicología Clínica Infantil y del Adolescente. Trastornos Específicos. Madrid: Ediciones Pirámide.

Cahn, D.A., Marcotte, A.C., Stern, R.A., Arruda, J.E., Akshoomoff, N.A., y Leshko, I.C. (1996). The Boston Qualitative Scoring System for the Rey-Osterrieth Complex Figure: A study of children with Attention Deficit Hyperactivity Disorder. The Clinical Neuropsychologist, 10(4), 397-406.

Cardo, E., y Servera, M. (2008). Trastorno por déficit de atención/hiperactividad: estado de la cuestión y futuras líneas de investigación. Revista de Neurología, 46(6), 365-372.

Cardo, E., Servera, M., Vidal, C., De Azua, B., Redondo, M., y Riutort, L. (2011). Influencia de los diferentes criterios diagnósticos y la cultura en la prevalencia del trastorno por déficit de atención/hiperactividad. Revista de Neurología, 52(1), 109-17.

Cardoso-Moreno, M.J., Tomás-Aragonés, L., y Rodríguez-Ledo, C. (2015). Socio-emotional intervention in attention deficit hyperactive disorder. European Journal of Education and Psychology, 8(2), 53-59. doi: 10.1016/j.ejeps.2015.07.001

Catelan-Mainardes, S.C. (2010). Transtorno de déficit de atenção e hiperatividade na infância e adolescência pela perspectiva da neurobiologia. Revista Saúde e Pesquisa, 3(3), 385391.

Corbett, B.A., Constantine, L.J., Hendren, R., Rocke, D., y Ozonoff, S. (2009). Examining executive functioning in children with autism spectrum disorder, attention deficit hyperactivity disorder and typical development. Psychiatry Research, 166, 210-222. doi: 10.1016/j.psychres.2008.02.005

Da Silva, A.M., Peçanha, E., Charchat-Fichman, H., Oliveira, R.M., y Correa, J. (2016). Estratégias de cópia da Figura Complexa de Rey por Crianças. Neuropsicologia Latinoamericana, 8(1), 12-21. doi: 10.5579/rn1.2016.0276

Etchepareborda, M.C., Díaz-Lucero, A., y De Ramón, I. (2011). Diagnóstico del TDAH. En M.C. Etchepareborda (Ed.), TDAH + FE: trastorno por déficit de atención con hiperactividad $y$ de las funciones ejecutivas: abordaje interdisciplinar, (pp.37-43). Buenos Aires: Autor.

Fernández-Jaén, A., Martín Fernández-Mayoralas, D., Fernández-Perrone, A.L., Calleja-Pérez, B., Albert, J., López-Martín, S., y López-Arribas, S. (2016). Disfunción en el trastorno por déficit de atención/hiperactividad: evaluación y respuesta al tratamiento [XVIII Curso Internacional de Actualización en Neuropediatría y Neuropsicología Infantil]. Revista de Neurología, 62(1), 79-84.

Filippetti, V., y Mías, C. (2009). Neuropsicología del trastorno por déficit de atención/hiperactividad: subtipos predominio déficit de atención y predominio hiperactivo-impulsivo.Revista Argentina de Neuropsicología, 13, 14-28.

García, M.T.I., Fernández, N.G., Loew, S.J., y Pérez, C.R. (2016). Hábitos y técnicas de estudio en adolescentes con trastorno por déficit de atención con o sin hiperactividad. European Journal of Education and Psychology, 9(1), 29-37. doi: 10.1016/j.ejeps.2015.07.002

Grañana, N., Richaudeau, A., Robles Gorriti, C., Scotti, M., Fejerman, N., y Allegri, R. (2006). Detección de síntomas para trastorno por déficit de atención e hiperactividad: escala SNAP IV, validación en Argentina. Revista Neurológica Argentina, 28(1), 20.

Kaufman, A.S. (2000).K-BIT: Test Breve de Inteligencia de Kaufman. Madrid: Tea.

Martín-González, R., González-Pérez, P.A., Izquierdo-Hernández, M., Hernández-Expósito, S., Alonso-Rodríguez, M.A., Quintero-Fuentes, I., y Rubio-Morell, B. (2008). Evaluación 
neuropsicológica de la memoria en el trastorno por déficit de atención/hiperactividad: papel de las funciones ejecutivas. Revista de Neurología, 47(5), 225-230.

Mayor, J.G., y García, R.S. (2011). Trastorno por Déficit de Atención/Hiperactividad (TDAH) Revisión ¿Hacia dónde vamos ahora? Revista Chilena de Psiquiatría y Neurología de la Infancia y la Adolescencia, 22(2), 144-154.

Missawa, D., Dadalto, A., y Rossetti, C.B. (2014). Psicólogos e TDAH: pos sí veis caminhos para diagnóstico e tratamento. Construção Psicopedagógica, 22(23), 81-90.

Montero, I., y Leon, O. (2007). A guide for naming research studies in Psychology. International Journal of Clinical and Health Psychology, 7(3), 847-862.

Montoya Londoño, D.M., Varela Cifuentes, V., y Dussán Lubert, C. (2011). Caracterización neuropsicológica de una muestra de niños y niñas con TDAH de la ciudad de Manizales. Biosalud, 10(1), 30-51.

Narbona, J., y Crespo Eguílaz, N. (2005). Trastornos de memoria y de atención en disfunciones cerebrales del niño. Revista de Neurología, 40(1), 33.

Nigg, J.T., Hinshaw, S.P., Carte, E., y Treuting, J. (1998). Neuropsychological correlates of antisocial behavior and comorbid disruptive behavior disorders in children with ADHD. Journal of Abnormal Psychology, 107, 468-480. doi: 10.1037/0021-843X.107.3.468

Osterrieth, P.A. (1944). Le test de copied' une figure complexe. Arch Psychological, 30, 206-356.

Pardo, A., y Ruiz, M. (2000). Spss 11 Guía para el Análisis de Datos. Análisis no Paramétrico. México: Mc Graw Hill.

Quezada, C. (2007). Potencia estadística, sensibilidad y tamaño de efecto: ¿un nuevo canon para la investigación? Onomázein, 16, 159-170.

Rey, A. (1997). Test de Copia y de Reproducción de Memoria de Figuras Geométricas Complejas. Madrid: TEA.

Rizzutti, S., Sinnes, E.G., Scaramuzza, L.F., Freitas, L., Pinheiro, D., Palma, S.M., ...y Muszkat, M. (2008). Clinical and neuropsychological profile in a sample of children with attention deficit hyperactivity disorders. Arquivos de Neuro-Psiquiatria, 66(4), 821-827.

Robinson, T., y Tripp, G. (2013). Neuropsychological functioning in children with ADHD: Symptom persistence is linked to poorer performance on measures of executive and nonexecutive function. Japanese Psychological Research, 55(2), 154-167.

Rodillo, B.E. (2015). Trastorno por déficit de atención e hiperactividad (TDAH) en adolescentes. Revista Médica Clínica Las Condes, 26(1), 52-59. doi: 10.1016/j.rmclc.2015.02.005.

Schreiber, H.E., Javorsky, D.J., Robinson, J.E., y Stern, R.A. (1999). Rey-Osterrieth Complex Figure Performance in adults with Attention Deficit Hyperactivity Disorder: A validation study of the Boston Qualitative Scoring System. The Clinical Neuropsychologist, 13(4), 509-520.

Soprano, A.M. (2003). Evaluación de las funciones ejecutivas en el niño. Revista de Neurología, $37(1), 44-50$.

Stern, R., Javorsky, D., Singer, E., Singer-Harris, N., Somerville, J., y Duke, L. (1999). The Boston Qualitative Scoring System. Odessa, FL: Psychological Assessment Resources Inc.

Strauss, E., Sherman, E.M.S., y Spreen, O. (2006). A Compendium of Neuropsychological Tests: Administration, Norms, and Commentary. New York: Oxford University Press.

Tirapu-Ustárroz, J., Muñoz-Céspedes, J.M., Pelegrín-Valero, C., y Albéniz-Ferreras, A. (2005). Propuesta de un protocolo para la evaluación de las funciones ejecutivas. Revista de Neurología, 41(3), 177-186.

Watanabe, K., Ogino, T., Nakano, K., Hattori, J., Kado, Y., Sanada, S., y Ohtsuka, Y. (2005). The Rey-Osterrieth Complex Figure as a measure of executive function in childhood. Brain and Development, 27(8), 564-569. doi:10.1016/j.braindev.2005.02.007 
RUBIALES et al. Organization strategies in the Rey-Osterrieth Complex Figure...

Willcutt, E.G. (2012). The prevalence of DSM-IV attention-deficit/hyperactivity disorder: a metaanalytic review. Neurotherapeutics, 9(3), 490-499. doi: 10.1007/s13311-012-0135-8.

Willcutt, E.G., Doyle, A.E., Nigg, J.T., Faraone, S.V., y Pennington, B.F. (2005). Validity of the executive function theory of attention-deficit/hyperactivity disorder: a meta-analytic review. Biological Psychiatry, 57(11), 1336-1346. doi: 10.1016/j.biopsych.2005.02.006

Received: February 22nd, 2017 Modifications received: May 19th, 2017 Accepted: May 21st, 2017 